13. Мелехова О. П., Егорова Е. И., Евсеева Т. И. и др. Биологический контроль окружающей среды: биоиндикация и биотестирование // Москва. 2007. 288 с.

14. Рахимов T. У. Фитоиндикация в оценке загрязнения окружающей среды // Наука и современность. 2012. Т. 16. № 1. С. 9-13.

15. Tарасов B. B. Флора Дніпропетровської і Запорізької областей // Дніпропетровськ. 2012. 296 с.

16. Шкаранда Ю. С., Корженевский В. В. Фитоиндикация экологической амплитуды популяции medicago marina l. на пересыпи о. Донузлав // Бюллетень ГНБС. 2015. Вып. 114. C. $13-19$.

17. Zhukov A., Zadorozhnaya G. Spatial heterogeneity of mechanical impedance of a typical chernozem: the ecological approach // Ekológia (Bratislava). 2016. Vol. 35. No. 3. P. 263.

Надійшла до редколегії 17.07.2016

Ю. Г. Приседський

Донещьький національний університет (м. Вінниия)

\title{
ВПЛИВ ЗАБРУДНЕННЯ СУЛЬФІТАМИ ТА ФТОРИДАМИ НА НАКОПИЧЕННЯ БІОМАСИ КВІТКОВИМИ РОСЛИНАМИ
}

Вивчено реакцію 7 видів квітково-декоративних рослин на забруднення грунту фторидами та сульфітами. Встановлено значну негативну дію забруднювачів на накопичення сирої та сухої маси усіма вивченими видами рослин. Найбільш стійкими за результатами дослідження виявилися кукіль звичайний (Agrostemma githago L.), космея жовтогаряча (Cosmos sulphureus Cav.), льон звичайний (Linum usitatissimum L.).

Ключові слова: декоративні рослини, механізми адаптації, стійкість.

\section{Ю. Г. Приседский}

\section{Донеикий наџиональный университет (2. Виннииа)}

\section{ВЛИЯНИЕ ЗАГРЯЗНЕНИЯ СУЛЬФИТАМИ И ФТОРИДАМИ НА НАКОПЛЕНИЕ БИОМАССЫ ЦВЕТОЧНЫМИ РАСТЕНИЯМИ}

Изучена реакция 7 видов цветочно-декоративных растений на загрязнение почвы фторидами и сульфитами. Установлено значительное негативное действие загрязнителей на накопление сырой и сухой массы изученными видами растений. Наиболее устойчивыми по результатам исследований являются куколь обыкновенный (Agrostemma githago L.), космея желтая (Cosmos sulphureus Cav.), лен обыкновенный (Linum usitatissimum L.).

Ключевые слова: декоративные растения, механизмы адаптации, устойчивость.

\author{
Ju. H. Pryesedeskyi \\ Donetsk National Univerity (m. Vinnitsa)
}

\section{THE IMPACT BY SULPHUR AND FLUORIDE ON THEACCUMULATION OF BIOMASS OFF ORNAMENTAL PLANTS}

Industrial soil pollution with heavy metals, sulphur, fluorine, chlorine, etc. has become important environmental factor that significantly affects plant organisms, causing their oppression. In this regard, we have studied the reaction of seven species of ornamental plants (Ageratum houstonianum cv. Bule Lagoon, Dahlia variabilis Desf., Echinacea purpurea L., Dahlia variabilis Desf., Calendula officinalis L., Cosmos sulphureus Cav.,

(C) Ю. Г. Приседський, 2016 
Agrostemma githago L., Atnplex hortensis L., Linum usitatissimum L., Petunia Hybrida Grandiflora L.) on contamination of the soil by sulphur and fluoride.

Significant negative impact of pollutants on the accumulation of wet and dry mass by all studied plant species has founded. So, plants Atnplex hortensis, Calendula officinalis, Dahlia variabilis, Echinacea purpurea and Petunia Hybrida are characterised by considerable (20,4-79,1\%) inhibition of the accumulation of green and dry mass in compared to plants grown in soil without any pollutants. Whereas in Agrostemma githago, Cosmos sulphureus, Linum usitatissimum and Ageratum houstonianum significant changes in the accumulation of green and dry mass of seedlings in dirt haven't observed.

There is a tendency to inhibition of wet mass in the plants by $18,7-24,7 \%$, which may indicate significant impairment of the synthetic processes and the water balance of plants at high doses of pollution. The common cockle Agrostemma githago, Cosmos sulphureus, Linum usitatissimum were the most resistance on results of the study.

Keywords: ornamental plants, industrial soil pollution, resistance.

Порушення екологічної рівноваги в результаті промислового забруднення довкілля призводить до збідніння флори, спричиняє необоротні зміни природних та штучних ландшафтів [4; 10]. Рослини є важливим компонентом довкілля, які виконують санітарно-гігієнічну та естетичну функції. Вони здатні накопичувати та утилізувати значну кількість забруднювачів та діоксиду карбону, зменшуючи тим самим навантаження промисловості на середовище $[2 ; 8 ; 9]$. Однак різні їх види неоднаково взаємодіють із промисловим забрудненням, що веде до формування комплексу індивідуальних реакцій, які полягають у зміні біохімічних та фізіологічних процесів, анатомічної структури та морфометричних показників $[1 ; 3 ; 5]$.

У зв'язку із цим метою нашої роботи було визначення впливу забруднення грунту сполуками фтору та сірки на накопичення біомаси деякими видами квітково-декоративних рослин для виявлення видів, стійких до забруднення грунту відходами підприємств хімічної промисловості.

Матеріали та методи досліджень.

Як об’єкти дослідження забруднення грунту було використано такі види рослин: агератум Гаустона (Ageratum houstonianum cv. Bule Lagoon), жоржина однорічна (Dahlia variabilis Desf.), ехінацея пурпурна (Echinacea purpurea L.), жоржина звичайна (Dahlia variabilis Desf.), календула звичайна (Calendula officinalis L.), космея жовтогаряча (Cosmos sulphureus Cav.), кукіль звичайний (Agrostemma githago L.), лобода садова (Atnplex hortensis L.), льон звичайний (Linum usitatissimum L.), петунія садова (Petunia Hybrida Grandiflora L.), які широко застосовуються в озелененні промислових зон України.

Насіння рослин пророщувалися відповідно до їх особливостей. Після утворення головного кореня довжиною близько 1 см проростки висаджувалися в посудини із грунтом, у який вносилися забруднювачі (сульфіт натрію та фторид натрію) відповідно до схеми повного двофакторного трирівневого експерименту (табл. 1).

Таблиия 1

Схема експерименту впливу забруднення грунту фтором і сіркою на квітково-декоративні рослини

\begin{tabular}{|c|c|c|}
\hline \multirow{2}{*}{ № варіанта } & \multicolumn{2}{|c|}{ Забруднювач } \\
\cline { 2 - 3 } & $\mathrm{NaF}, \mathrm{мг} /$ кг (у перерахуванні на $\left.\mathrm{F}^{-}\right)$ & $\mathrm{Na}_{2} \mathrm{SO}_{3}, \Gamma /$ кг (у перерахуванні на $\left.\mathrm{S}^{-2}\right)$ \\
\hline 1 & 0 & 0 \\
\hline 2 & 100 & 0 \\
\hline 3 & 200 & 0 \\
\hline 4 & 0 & 1 \\
\hline 5 & 100 & 1 \\
\hline
\end{tabular}


Закінчення табл. 1

\begin{tabular}{|c|c|c|}
\hline \multirow{2}{*}{ № варіанта } & \multicolumn{2}{|c|}{ Забруднювач } \\
\cline { 2 - 3 } & $\mathrm{NaF}, \mathrm{мг} /$ кг (у перерахуванні на $\left.\mathrm{F}^{-}\right)$ & $\mathrm{Na}_{2} \mathrm{SO}_{3}$, г/кг (у перерахуванні на $\left.\mathrm{S}^{-2}\right)$ \\
\hline 6 & 200 & 1 \\
\hline 7 & 0 & 2 \\
\hline 8 & 100 & 2 \\
\hline 9 & 200 & 2 \\
\hline
\end{tabular}

Під час досліду у проростків вимірювали сиру та суху масу. Отримані дані піддавалися статистичній обробці за методом двофакторного дисперсійного аналізу. Порівняння середніх здійснювалося за методикою Данета. Розрахунки проводилися з використанням ПБОМ [6;7].

\section{Результати та їх обговорення.}

Результати проведених досліджень свідчать про значні відмінності у реакціях рослин досліджених видів на фторидно-сульфітне забруднення грунту (табл. 2). Так, у кукіля звичайного, космеї жовтогарячої та льону звичайного не спостерігається вірогідних змін накопичення сирої та сухої маси проростками в усіх варіантах забруднення. Разом з тим забруднення грунту сіркою (вар. 5) у кукіля та космеї викликає тенденцію до зменшення накопичення біомаси на 20,1 та 9,6 \% порівняно $з$ контрольними рослинами відповідно. Найбільш несприятливими умовами росту для космеї жовтогарячої виявилося комплексне забруднення грунту фторидом та сульфітом натрію (вар. 8,9 ). За цих умов накопичення сирої маси знижується на 13,7-21,2 \%, хоча суха маса залишається практично незмінною і становить 96,4-99,3 \% від рівня контролю. Фторидне забруднення (вар. 2, 3) в усіх трьох видів рослин викликає тенденцію до збільшення сирої маси на 14,9 \%.

В агератуму забруднення грунту практично не чинить вірогідного впливу на накопичення сирої маси рослин. Лише високі концентрації фторидів, сульфітів та комплексної дії полютантів викликають тенденцію до зменшення накопичення сирої маси рослинами на 18,7-24,7 \% порівняно 3 рослинами, вирощуваними на незабрудненому грунті. Разом з тим суха маса рослин цього виду вірогідно знижується для усіх варіантів внесення забруднювачів і становить 20,7-53,4 \% від маси контрольних рослин. Це може свідчити про значне порушення синтетичних процесів та водного процесу рослин.

Рослини лободи садової, календули лікарської, жоржини однорічної, ехінацеї пурпурової та петунії гібридної характеризуються значним $(79,1-20,4$ \%) пригніченням накопичення сирої та сухої маси порівняно з рослинами, вирощуваними на грунті без внесення забруднювачів. Ці зміни значною мірою залежать від складу полютантів. Так, для ехінацеї та лободи найбільш небезпечним виявилося фторидне забруднення, тоді як сульфатне є менш небезпечним. Реакція календули та петунії залежить переважно від концентрації забруднювачів, а не від їх складу, i зростає із збільшенням вмісту полютантів у грунті (табл. 2).

Таким чином, спостерігаються суттєві відмінності у реакції вивчених видів квітково-декоративних рослин на фторидно-сульфітне забруднення грунту. Найбільш стійкими виявилися кукіль звичайний, космея жовтогаряча та льон звичайний.

Таблиия 2

Вплив забруднення грунту на накопичення біомаси квітковими декоративними рослинами

\begin{tabular}{|c|c|c|c|c|c|c|c|c|}
\hline \multirow{2}{*}{ 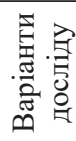 } & \multicolumn{4}{|c|}{ Сира маса рослини, г } & \multicolumn{4}{|c|}{ Суха маса рослини, г } \\
\hline & $\mathrm{M} \pm \mathrm{m}$ & $\mathrm{D}$ & $\mathrm{D}^{\mathrm{D}}$ & 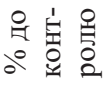 & $\mathrm{M} \pm \mathrm{m}$ & $\mathrm{D}$ & $\mathrm{D}^{\mathrm{D}}$ & 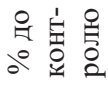 \\
\hline \multicolumn{9}{|c|}{ Ageratum houstonianum cv, Bule Lagoon } \\
\hline 1 & $1,714 \pm 0,730$ & - & - & 100,0 & $0,305 \pm 0,053$ & - & - & 100,0 \\
\hline
\end{tabular}


ISSN 2073-8331. Питання степового лісознавства та лісової рекультивації земель. Том 45, 2016

Продовження табл. 2

\begin{tabular}{|c|c|c|c|c|c|c|c|c|}
\hline \multirow{2}{*}{ 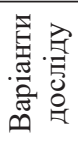 } & \multicolumn{4}{|c|}{ Сира маса рослини, г } & \multicolumn{4}{|c|}{ Суха маса рослини, г } \\
\hline & $\mathrm{M} \pm \mathrm{m}$ & $\mathrm{D}$ & $\mathrm{D}^{\mathrm{D}}$ & 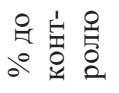 & $\mathrm{M} \pm \mathrm{m}$ & $\mathrm{D}$ & $\mathrm{D}^{\mathrm{D}}$ & 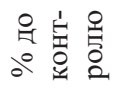 \\
\hline 2 & $1,374 \pm 0,061$ & $-0,340$ & 0,423 & 80,2 & $0,085 \pm 0,009$ & $-0,220$ & 0,246 & 27.9 \\
\hline 3 & $1,339 \pm 0,232$ & $-0,375$ & 0,707 & 78,1 & $0,084 \pm 0,021$ & $-0,221$ & 0,240 & 27,5 \\
\hline 4 & $1,804 \pm 0,308$ & 0,090 & 0,707 & 105,2 & $0,138 \pm 0,020$ & $-0,167$ & 0,251 & 45,2 \\
\hline 5 & $2,133 \pm 0,602$ & 0,419 & 0,707 & 124,4 & $0,092 \pm 0,030$ & $-0,213$ & 0,251 & 30,2 \\
\hline 6 & $1,291 \pm 0,163$ & $-0,423$ & 0,677 & 75,3 & $0,110 \pm 0,018$ & $-0,195$ & 0,251 & 36,1 \\
\hline 7 & $1,500 \pm 0,202$ & $-0,214$ & 0,630 & 87,5 & $0,163 \pm 0,082$ & $-0,142$ & 0,212 & 53,4 \\
\hline 8 & $1,569 \pm 0,079$ & $-0,145$ & 0,707 & 91,5 & $0,133 \pm 0,016$ & $-0,172$ & 0,251 & 43,6 \\
\hline 9 & $1,393 \pm 0,120$ & $-0,321$ & 0,707 & 81,3 & $0,063 \pm 0,006$ & $-0,242$ & 0,251 & 20,7 \\
\hline \multicolumn{9}{|c|}{ Agrostemma githago } \\
\hline 1 & $0,727 \pm 0,001$ & - & - & 100,0 & $0,067 \pm 0,001$ & - & - & 100,0 \\
\hline 2 & $0,869 \pm 0,038$ & 0,142 & 0,226 & 119,5 & $0,077 \pm 0,004$ & 0,010 & 0,060 & 114,9 \\
\hline 3 & $0,891 \pm 0,077$ & 0,164 & 0,226 & 122,6 & $0,077 \pm 0,006$ & 0,010 & 0,060 & 114,9 \\
\hline 4 & $0,786 \pm 0,042$ & 0,059 & 0,226 & 108,1 & $0,068 \pm 0,005$ & 0,001 & 0,060 & 101,5 \\
\hline 5 & $0,581 \pm 0,021$ & $-0,146$ & 0,226 & 79,9 & $0,049 \pm 0,001$ & $-0,018$ & 0,060 & 73,1 \\
\hline 6 & $0,910 \pm 0,042$ & 0,183 & 0,226 & 125,2 & $0,082 \pm 0,005$ & 0,015 & 0,060 & 122,4 \\
\hline 7 & $0,917 \pm 0,067$ & 0,190 & 0,226 & 126,1 & $0,082 \pm 0,006$ & 0,015 & 0,060 & 122,4 \\
\hline 8 & $0,803 \pm 0,078$ & 0,076 & 0,226 & 110,5 & $0,057 \pm 0,008$ & $-0,010$ & 0,060 & 85,1 \\
\hline 9 & $0,768 \pm 0,033$ & 0,041 & 0,226 & 105,6 & $0,066 \pm 0,003$ & $-0,001$ & 0,060 & 98,5 \\
\hline \multicolumn{9}{|c|}{ Atriplex hortense $L}$. \\
\hline 1 & $0,276 \pm 0,130$ & - & - & 100,0 & $0,104 \pm 0,095$ & - & - & 100,0 \\
\hline 2 & $0,174 \pm 0,055$ & $-0,102$ & 0,260 & 63,3 & $0,008 \pm 0,005$ & $-0,096$ & 0,064 & 7,7 \\
\hline 3 & $0,171 \pm 0,030$ & $-0,105$ & 0,260 & 61,9 & $0,010 \pm 0,001$ & $-0,094$ & 0,064 & 9,6 \\
\hline 4 & $0,207 \pm 0,047$ & $-0,069$ & 0,260 & 75,7 & $0,012 \pm 0,003$ & $-0,092$ & 0,064 & 11,5 \\
\hline 5 & $0,172 \pm 0,020$ & $-0,104$ & 0,260 & 62,5 & $0,010 \pm 0,002$ & $-0,094$ & 0,064 & 9,6 \\
\hline 6 & $0,172 \pm 0,028$ & $-0,104$ & 0,260 & 62,5 & $0,015 \pm 0,004$ & $-0,089$ & 0,064 & 14,4 \\
\hline 7 & $0,218 \pm 0,012$ & $-0,058$ & 0,260 & 79,0 & $0,022 \pm 0,001$ & $-0,082$ & 0,064 & 21,2 \\
\hline 8 & $0,214 \pm 0,066$ & $-0,062$ & 0,260 & 77,5 & $0,021 \pm 0,007$ & $-0,086$ & 0,064 & 20,2 \\
\hline 9 & $0,198 \pm 0,068$ & $-0,078$ & 0,260 & 71,7 & $0,020 \pm 0,007$ & $-0,084$ & 0,064 & 19,2 \\
\hline \multicolumn{9}{|c|}{ Calendula officinalis $L}$. \\
\hline 1 & $2,910 \pm 0,088$ & - & - & 100,0 & $0,338 \pm 0,030$ & - & - & 100,0 \\
\hline 2 & $1,826 \pm 0,001$ & $-1,111$ & 0,529 & 62,7 & $0,780 \pm 0,408$ & 0,442 & 0,236 & 230,8 \\
\hline 3 & $1,602 \pm 0,032$ & $-1,308$ & 0,526 & 55,1 & $0,157 \pm 0,036$ & $-0,181$ & 0,235 & 46,4 \\
\hline 4 & $1,463 \pm 0,041$ & $-1,447$ & 0,529 & 50,3 & $0,145 \pm 0,001$ & $-0,193$ & 0,236 & 42,9 \\
\hline 5 & $1,802 \pm 0,319$ & $-1,108$ & 0,529 & $61,-$ & $0,128 \pm 0,050$ & $-0,21$ & 0,236 & 37,9 \\
\hline 6 & $0,974 \pm 0,001$ & $-1,936$ & 0,449 & 33,5 & $0,067 \pm 0,001$ & $-0,271$ & 0,201 & 19,8 \\
\hline 7 & $0,869 \pm 0,003$ & $-2,041$ & 0,529 & 29,9 & $0,067 \pm 0,001$ & $-0,271$ & 0,236 & 19,8 \\
\hline 8 & $0,747 \pm 0,032$ & $-2,163$ & 0,529 & 25,7 & $0,058 \pm 0,007$ & $-0,280$ & 0,236 & 17,2 \\
\hline 9 & $0,747 \pm 0,032$ & $-2,163$ & 0,487 & 25,7 & $0,039 \pm 0,013$ & $-0,299$ & 0,236 & 11,5 \\
\hline \multicolumn{9}{|c|}{ Cosmos sulphureus Cav. } \\
\hline 1 & $0,415 \pm 0,007$ & - & - & 100,0 & $0,137 \pm 0,001$ & - & - & 100,0 \\
\hline 2 & $0,477 \pm 0,217$ & 0,062 & 0,169 & 114,9 & $0,205 \pm 0,193$ & 0,068 & 0,100 & 149,6 \\
\hline 3 & $0,388 \pm 0,026$ & $-0,027$ & 0,160 & 93,5 & $0,133 \pm 0,001$ & $-0,004$ & 0,093 & 97,1 \\
\hline 4 & $0,341 \pm 0,171$ & $-0,074$ & 0,179 & 82,23 & $0,129 \pm 0,015$ & $-0,008$ & 0,096 & 94,2 \\
\hline 5 & $0,375 \pm 0,049$ & $-0,040$ & 0,189 & 90,4 & $0,131 \pm 0,005$ & $-0,006$ & 0,104 & 95,6 \\
\hline 6 & $0,404 \pm 0,118$ & $-0,011$ & 0,189 & 99,8 & $0,126 \pm 0,121$ & 0,089 & 0,101 & 94,2 \\
\hline 7 & $0,429 \pm 0,039$ & 0,014 & 0,169 & 103,4 & $0,134 \pm 0,003$ & $-0,003$ & 0,098 & 97,8 \\
\hline 8 & $0,372 \pm 0,010$ & $-0,043$ & 0,184 & 78,8 & $0,132 \pm 0,003$ & $-0,005$ & 0,088 & 96,4 \\
\hline 9 & $0,358 \pm 0,038$ & $-0,057$ & 0,189 & 86,3 & $0,136 \pm 0,004$ & $-0,001$ & 0,104 & 99,3 \\
\hline
\end{tabular}


Закінчення табл. 2

\begin{tabular}{|c|c|c|c|c|c|c|c|c|}
\hline \multirow{2}{*}{ 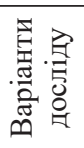 } & \multicolumn{4}{|c|}{ Сира маса рослини, г } & \multicolumn{4}{|c|}{ Суха маса рослини, г } \\
\hline & $\mathrm{M} \pm \mathrm{m}$ & $\mathrm{D}$ & $\mathrm{D}^{\mathrm{D}}$ & 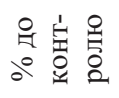 & $\mathrm{M} \pm \mathrm{m}$ & $\mathrm{D}$ & $\mathrm{D}^{\mathrm{D}}$ & 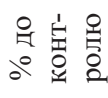 \\
\hline \multicolumn{9}{|c|}{ Dahlia variabilis Desf. } \\
\hline 1 & $2,238 \pm 0,126$ & - & - & 100,0 & $0.232 \pm 0.010$ & - & - & 100,0 \\
\hline 2 & $1,885 \pm 0,140$ & -0.353 & 0.352 & 84,2 & $0.179 \pm 0.006$ & -0.053 & 0.018 & 77,2 \\
\hline 3 & $1,840 \pm 0,179$ & -0.398 & 0.352 & 82,2 & $0.168 \pm 0.005$ & -0.064 & 0.018 & 72,4 \\
\hline 4 & $1,770 \pm 0,066$ & -0.468 & 0.352 & 79,1 & $0.176 \pm 0.004$ & -0.056 & 0.018 & 75,9 \\
\hline 5 & $1,813 \pm 0,133$ & -0.425 & 0.352 & 80,6 & $0.157 \pm 0.008$ & -0.075 & 0.018 & 67,7 \\
\hline 6 & $1,264 \pm 0,107$ & -0.974 & 0.352 & 56,6 & $0.163 \pm 0.005$ & -0.069 & 0.018 & 70,3 \\
\hline 7 & $0,928 \pm 0,077$ & -1.310 & 0.352 & 41,5 & $0.167 \pm 0.005$ & -0.065 & 0.018 & 72,0 \\
\hline 8 & $0,757 \pm 0,110$ & -1.481 & 0.352 & 33,8 & $0.162 \pm 0.005$ & -0.070 & 0.018 & 69,8 \\
\hline 9 & $0,739 \pm 0,109$ & -1.499 & 0.352 & 33,0 & $0.137 \pm 0.006$ & -0.094 & 0.018 & 59,1 \\
\hline \multicolumn{9}{|c|}{ Echinacea purpurea $L}$. \\
\hline 1 & $0,193 \pm 0,041$ & - & - & 100,0 & $0,011 \pm 0,003$ & - & - & 100,0 \\
\hline 2 & $0,155 \pm 0,010$ & $-0,038$ & 0,214 & 78,1 & $0,031 \pm 0,017$ & 0,019 & 0,140 & 281.8 \\
\hline 3 & $0,139 \pm 0,008$ & $-0,054$ & 0,214 & 72,0 & $0,082 \pm 0,046$ & 0,070 & 0,140 & 745,5 \\
\hline 4 & $0,243 \pm 0,105$ & 0,050 & 0,214 & 127,5 & $0,110 \pm 0,075$ & 0,099 & 0,140 & 1000,0 \\
\hline 5 & $0,099 \pm 0,033$ & $-0,094$ & 0,214 & 46,6 & $0,025 \pm 0,010$ & 0,013 & 0,140 & 227,3 \\
\hline 6 & $0,346 \pm 0,133$ & 0,153 & 0,214 & 179,3 & $0,072 \pm 0,062$ & 0,060 & 0,140 & 6754,5 \\
\hline 7 & $0,192 \pm 0,043$ & $-0,001$ & 0,214 & 99 & $0,014 \pm 0,002$ & $-0,003$ & 0,140 & 127,3 \\
\hline 8 & $0,213 \pm 0,066$ & 0,020 & 0,214 & 110,4 & $0,061 \pm 0,065$ & 0,049 & 0,140 & 609,1 \\
\hline 9 & $0,154 \pm 0,008$ & $-0,039$ & 0,214 & 79,8 & $0,017 \pm 0,010$ & 0,005 & 0,140 & 154,5 \\
\hline \multicolumn{9}{|c|}{ Linum usitatissimum $L}$. \\
\hline 1 & $0,168 \pm 0,008$ & - & - & 100,0 & $0,009 \pm 0,002$ & - & - & 100,0 \\
\hline 2 & $0,199 \pm 0,001$ & 0,031 & 0,174 & 118,5 & $0,016 \pm 0,001$ & 0,007 & 0,012 & 177,8 \\
\hline 3 & $0,235 \pm 0,001$ & 0,067 & 0,174 & 139,9 & $0,013 \pm 0,001$ & 0,004 & 0,012 & 144,4 \\
\hline 4 & $0,189 \pm 0,001$ & 0,021 & 0,174 & 112,5 & $0,012 \pm 0,001$ & 0,003 & 0,012 & 133,3 \\
\hline 5 & $0,167 \pm 0,001$ & $-0,001$ & 0,174 & 99,4 & $0,011 \pm 0,004$ & 0,002 & 0,012 & 122,2 \\
\hline 6 & $0,417 \pm 0,001$ & 0,249 & 0,174 & 248,2 & $0,017 \pm 0,001$ & 0,008 & 0,012 & 188,9 \\
\hline 7 & $0,206 \pm 0,034$ & 0,038 & 0,174 & 122,6 & $0,010 \pm 0,002$ & 0,001 & 0,012 & 111,1 \\
\hline 8 & $0,197 \pm 0,021$ & 0,029 & 0,174 & 117,3 & $0,013 \pm 0,002$ & 0,004 & 0,012 & 144,4 \\
\hline 9 & $0,226 \pm 0,010$ & 0,058 & 0,174 & 134,5 & $0,015 \pm 0,001$ & 0,006 & 0,012 & 166,7 \\
\hline \multicolumn{9}{|c|}{ Petunia Hybrida Grandiflora L. } \\
\hline 1 & $0,422 \pm 0,098$ & - & - & 100,0 & $0,118 \pm 0,053$ & - & - & 100,0 \\
\hline 2 & $0,281 \pm 0,178$ & $-0,141$ & 0,339 & 68,9 & $0,122 \pm 0,008$ & 0,004 & 0,136 & 103,4 \\
\hline 3 & $0,218 \pm 0,002$ & $-0,204$ & 0,339 & 51,7 & $0,104 \pm 0,001$ & $-0,014$ & 0,136 & 88,1 \\
\hline 4 & $0,279 \pm 0,047$ & $-0,143$ & 0,339 & 66,1 & $0,119 \pm 0,005$ & 0,001 & 0,136 & 100,8 \\
\hline 5 & $0,258 \pm 0,063$ & $-0,165$ & 0,339 & 61,1 & $0,089 \pm 0,051$ & $-0,030$ & 0,136 & 75,4 \\
\hline 6 & $0,152 \pm 0,059$ & $-0,270$ & 0,339 & 36,0 & $0,115 \pm 0,001$ & $-0,003$ & 0,136 & 97,5 \\
\hline 7 & $0,696 \pm 0,096$ & 0,273 & 0,339 & 164,9 & $0,079 \pm 0,075$ & $-0,039$ & 0,136 & 66,9 \\
\hline 8 & $0,315 \pm 0,104$ & $-0,108$ & 0,339 & 74,6 & $0,054 \pm 0,061$ & $-0,064$ & 0,136 & 45,8 \\
\hline 9 & $0,130 \pm 0,156$ & $-0,292$ & 0,339 & 30,8 & $0,056 \pm 0,068$ & $-0,062$ & 0,136 & 47,5 \\
\hline
\end{tabular}

\section{Бібліографічні посилання}

1. Амосова Н. В., Тазина И. А., Сынзыныс Б. И. Фито- и генотоксическое действие ионов железа, кобальта и никеля на физиологические показатели растений различных видов // Сельскохозяйственная биология. 2003. № 5. С. 49-54.

2. Безсонова В. П., Фендюр Л. М., Пересипкіна Т. М. Можливості використання декоративних квіткових рослин для фітоіндикації забруднення навколишнього середовища // Укр. ботан. журн. 1996. Т. 53. № 3. С. 225-231. 
3. Бессонова В. П., Козюкина Ж. Т., Лыюенко И. И. Влияние избытка микроэлементов и двуокиси серы на световые реакции фотосинтеза в хлоропластах гороха // Физиология и биохимия культ. растений. 1990. 22. № 3. С. 220-225.

4. Зурнаджи T. Г., Пельтіхіна P. I. Адаптивні можливості деяких квітково-декоративних рослин в умовах техногенного середовища // Укр. ботан. журн. 1997. Т. 54. № 1. C. $68-70$.

5. Приседский Ю.Г., Максимов В.М. Влияние загрязнения среды соединениями фтора, серы и азота на ростовые процессы проростков робинии псевдоакации // Промышленная ботаника: состояние и перспективы развития: материалы Третьей Междунар. науч. конф. (Донецк, 3-5 сентября 1998 г.). Донецк. 1998. С. 289-291.

6. Приседський Ю. Г. Програми статистичної обробки експериментальних даних. Донецьк. 2000. 15 с.

7. Приседський Ю. Г. Статистична обробка результатів біологічних експериментів. Донецьк. 1999. 210 с.

8. Тарабрин В. П., Кондратюк Е. Н., Башкатов В. Г. и др. Фитотоксичность органических и неорганических загрязнителей. Киев. 1986. 216 с.

9. Environmental monitoring of fluoride emission using precipitation, dust, plant and soil samples /J. Franzaring at al. //Environmental Pollution. 2006. Vol. 144. N 1. P. 158-165.

10. Glick B. R. Phytoremediation: synergistic use of plants and bacteria to clean up the environment // Biotechnology Advances. 2003. Vol. 21. N 5. P. 383-393.

Надійшла до редколегії 29.07.2016 p.

Н. О. Рощина

НДІ біології Дніпропетровського начіонального університету

імені Олеся Гончара

\section{ФЛОРОЦЕНОТИЧНЕ РІЗНОМАНІТТЯ ОЗЕР ПРИСАМАР'Я У ПОРІВНЯННІ ЗІ ШТУЧНИМИ ВОДОЙМАМИ}

Представлено результати досліджень флори водойм долини р. Самари. Наведено список та проведено аналіз водної флори та ценозів озер та штучних водойм. Найбільшим флороценотичним різноманіттям відрізняються водойми заплави та арени ріки Самари, найменшим - штучні водойми. Це пов'язано зі ступенем антропогенного впливу, а також гідрологічними та геоморфологічними особливостями умов існування видів.

Ключові слова: флора, рослинність, озера, ставки, антропогенний вплив.

\section{Н. О. Рощина}

НИИ биологии Днепропетровского национального университета имени Олеся Гончара

\section{ФЛОРОЦЕНОТИЧЕСКОЕ РАЗНООБРАЗИЕ ОЗЕР ПРИСАМАРЬЯ В СРАВНЕНИИ С ИСКУССТВЕННЫМИ ВОДОЕМАМИ}

Освещены результаты исследований флоры водоемов долины р. Самары. Представлен список и проведен анализ водной флоры и ценозов озер и искусственных водоемов. Наибольшим флороценотическим разнообразием отличаются водоемы поймы и арены реки Самары, наименьшим - искусственные водоемы. Это связано со степенью антропогенного влияния, а также гидрологическими и геоморфологическими особенностями условий существования видов.

Ключевые слова: флора, растительность, озера, пруды, антропогенное влияние.

(C) Н. О. Рощина, 2016 